\title{
INTERPERSONAL METAPHOR OF MOOD APPLIED TO SOME VERSES OF THE HOLY AL-OUR'AN
}

\author{
Jumino Suhadi \\ Fakultas Sastra Universitas Islam Sumatera Utara \\ J1. Sisingamangaraja, Medan, Sumatera Utara, 20143 \\ e-mail: jumino@sastra-uisu.ac.id
}

\begin{abstract}
Abstrak: Penerapan Modalitas Metafora Interpersona pada Ayat-Ayat Suci al-Qur'an. Artikel ini merupakan hasil penelitian deskriptif kualitatif yang menguji teori moda metafora interpersonal yang digagas oleh Halliday (1994) apakah relevan diaplikasikan pada ayat-ayat suci al-Qur'an. Metafora interpersona yang dipergunakan dalam survey ini meliputi tiga jenis moda yaitu moda indikatif, moda interogatif dan moda imperatif. Akan tetapi penelitian ini tidak mencakup metafora interpersonal modalitas. Hasil penelitian ini menunjukkan bahwa banyak ayat suci al-Qur'an yang menggunakan transfer moda dalam mengemukakan pesan: sebahagian moda indikatif diekspresikan dalam bentuk interogatif dan imperatif, sebahagian moda imperatif diekspresikan dalam bentuk indikatif dan interogatif, dan beberapa moda interogatif diekspresikan dalam moda indikatif dan imperatif. Hal ini berarti bahwa teori metafora interpersona yang dipelopori Halliday dapat disahkan sebagai teori linguistik yang memenuhi standar.
\end{abstract}

\begin{abstract}
This article is the result of a descriptive qualitative research which examine to what extent the theory of Interpersonal Metaphor of mood postulated by Halliday (1994) is relevant to be applied to the verses of the Holy al-Qur'an. The Interpersonal Metaphor applied in this survey covers the three kinds of mood which constitute indicative mood, interrogative mood and imperative mood. This work, however, does not cover the Interpersonal Metaphor of modality. The result shows that some verses of the Holy al-Qur'an use the transference of mood in conveying messages: some indicative moods are expressed in the interrogative and imperative, some imperative moods in the indicative and interrogative, and some interrogative moods in the indicative and imperative. The writer maintains that Halliday's theory of Interpersonal Metaphor can be justified as an adequate linguistic theory.
\end{abstract}

Keywords: systemic functional linguistics, interpersonal metaphor, al-Qur'an, literature 


\section{Introduction}

Metaphor is differentiated into two main types: lexical metaphor and grammatical metaphor. Lexical metaphor is the representation of an incongruent expression involving the use of a lexical item for a comparison with an emphasis on similarity. For instance, the word wheel in the wheel of the car is literally used, as the word wheel normally collocates with vehicles such as car, bus, truck, etc. However, the word wheel in the phrase the wheel of life is metaphorically used, as the word wheel does not collocate with the word life as the former refers to something concrete whereas the latter refers to something abstract.

Grammatical metaphor, on the other hand, is an incongruent coding which involves a change on the lexico-grammatical structure of a clause. Grammatical Metaphor divides into Ideational Metaphor and Interpersonal Metaphor. Ideational metaphor is an incongruent coding involving the changes on the lexico-grammatical structure of a clause. For instance, a literal coding such as the meaning of the word cannot be described in words but it can be explained through examples, may be transferred into a metaphorical coding to become The word meaning is indescribable except through examples. Interpersonal metaphor, further, divides into two: involving changes in the modality, for instance, the clause He can swim, which is in the congruent coding, can be expressed in the interpersonal metaphor of modality asHe is able to swim; or He has an ability to swim, and involving changes on the speech function (mood), for example, a question such as Where is my pen Mom?, is normally answered in the indicative mood Your pen is in the drawer; which is in the congruent coding; but, it may be expressed in the imperative mood such as Find it in the drawer, or in the interrogative mood: Have you looked for it in the drawer?, which are relatively incongruent known as Interpersonal metaphor of mood. ${ }^{1}$

This paper is an attempt to examine if the theory of Interpersonal Metaphor of Mood is relevant to be applied to analyze verses of the Holy al-Quran (henceforth HQ). The theoretical framework applied in the analysis is, therefore, the theory of Systemic Functional Linguistics (SFL) pioneered by Halliday (1994). Thus, this is a text analysis of qualitative data. ${ }^{2}$ The corpora of data were derived from the verses of the HQ. Totally, there are 6632 verses in the HQ. The data were randomly selected to suit the relevance of the subject matter and three clauses for each type were applied. The data adopted were in Latin transliteration from NazriAdlani (2008) and adjusted to the in-house style of Miqot UIN Medan. The English translation of the HQ was quoted from an outstanding translator Abdullah Yusuf Ali (1983). p. 202.

${ }^{1}$ Jumino Suhadi, Course in English Functional Grammar (Medan: LPPM UISU Press, 2015),

${ }^{2}$ Mahsun, Metode Penelitian Bahasa: Tahapan Strategi, Metode dan Tekniknya (Jakarta: RajaGrafindo Persada, 2007), p. 219. 


\section{An Overview of Systemic Functional Linguistics}

Systemic Functional Linguistics was introduced by M.A.K. Halliday in England in 1961 through several seminal papers. In the seventies he moved to Australia to establish the Department of Linguistics at the University of Sydney. In this department he introduced the theory to his students and finally SFL has spread to a number of institutions in Australia and many parts of the world. SFL, which is also known as Systemic Functional Grammar (SFG), is a model of grammar which constitutes part of a broad social semiotic approach to language called systemic linguistics. The term systemic refers to the view of language as a network of systems for making meaning; the term functional indicates that the approach focused on three metafunctions of language.Initially, Halliday's theory of SFG by his publication Systemic Background in 1985 did not get much attention from other linguists. Finally, in 1994 he published a more comprehensive monograph entitled An Introduction to Functional Grammar and now it becomes the main reference of the theory of SFG by most Functional Grammarians across the globe.

In SFG, language is viewed as a resource for making meaning and so it describes language in its actual use in terms of texts and their contexts. Therefore, this theory attempts to describe how the structures of a text construct meanings and how the meanings of the text can be realized. Halliday (1994) explains that a language consists of a set of systems and the speaker or the writer may choose the ways of expressing meanings. When people use a language to express meanings, they do so in specific situations, and the form of the language that they use is influenced by the complex elements of those situations. Thus, it is with these ideas that Halliday means by his theory of Systemic Functional Grammar. He claims that all adult language is organized around a small number of functional components which correspond to the metafunction of language which underlie all language use and these metafunctions have a systematic relationship with the lexicogrammar of the language.

Language is used in three different functions known as the three metafunctions of language. These metafunctions are the ideational, the interpersonal and the textual. The ideational function means that language is used to organize, understand and express the speaker's perceptions of the world and of his consciousness, and this function divides into two: the experientialfunction and the logical function. The experiential function is largely concerned with contents or ideas which regard clauses as the representations of experience in terms of transitivity structures, which are represented with processes and associated with participants and circumstances. The logical function is concerned with the relationship between ideas in clause complexes. It defines the logico-semantic relation between one clause and another which covers expansion and projection and it also defines clause complexes from the interdependency relation whether they are paratactic or hypotactic.

The interpersonal function means that language is used to enable the speaker to participate in communicative acts with other people, to take on roles and to express and misunderstand feelings, attitude and judgments. This function involves mood structures 
and modality. Mood Structures express interactional meanings such as what the clause is doing, as a verbal exchange between the encoder and the decoder. Modality, which covers modalization and modulation, refers to opinion or judgment of the speaker on the content and speech function of the clause. Modalization covers probability and usuality and modulation covers obligation and inclination.

The textual function means that language is used to relate what is said or written to the real world and to other linguistic events. This involves the use of language to organize the text itself in terms of thematic structures, covering theme and rheme, which express the organization of the message; how the clause relates the surrounding discourse to the context of situation in which it is being produced. In addition, the unity of meaning in text known as cohesion constitutes the realization of the textual function.

Halliday (1994) maintains that the three Meta functions of language noted above operate simultaneously in the expression of meaning because certain aspects of the grammar realize the ideational function, other aspects realize the interpersonal function, and yet others realize the textual function. These functions also determine the structural shape of the clause and have moulded the shape of language and fixed the course of its evolution and this claim is the basis of the theory of functional grammar. ${ }^{3}$

\section{Grammatical Metaphor in SFL}

Grammatical metaphor is the transference in the expression of meanings from a congruent representation to another incongruent realization which involves changes in the level of clauses, groups/phrases, words and morphemes. Grammatical metaphor divides into two types: Ideational Metaphor and Interpersonal Metaphor.

Ideational metaphor is incongruent coding involving transferences from the congruent form of types of the clauses and types of the processes and the participants used. For instance, the congruent expression such as He departed to the station immediately so that he was safe from the fatal accident may be transferred into its corresponding grammatical metaphoric expression His immediate departure to the station saved him from the fatal accident. ${ }^{4}$

Such incongruent coding which is characterized by high degree of lexical density and low degree of grammatical intricacy is generally used in the written language. On the other hand, congruent coding which is characterized by low degree of lexical density and high degree of grammatical intricacy is used in the spoken language.

An expression is said to be congruent if it is coded by using the normal grammatical categories in terms of experiential functions as given below: a thing coded by a noun, an

${ }^{3}$ M.A.K. Halliday, An Introduction to Functional Grammar (London: Edward Arnold, 1994), p. 35-36.

${ }^{4} I b i d .$, p. 342-343. 
event or activity coded by a process, quality coded by an adjective, location, time, manner coded by a circumstance, relation coded by a conjunction, position coded by a preposition, and judgment, opinion or comment coded by modality.

Here are some other examples of literal coding with their related grammatical metaphoric coding.

\begin{tabular}{|l|l|}
\hline \multicolumn{1}{|c|}{ Congruent Coding } & \multicolumn{1}{|c|}{ Grammatical Metaphoric Coding } \\
\hline 1a. Thank you because you come here. & 1b. Thank you for your coming here. \\
\hline $\begin{array}{l}\text { 2a. This country is stable and so the crisis is } \\
\text { solved. }\end{array}$ & $\begin{array}{l}\text { 2b. The stability of this country leads to the } \\
\text { solution to the crisis. }\end{array}$ \\
\hline $\begin{array}{l}\text { 3a. Law enforcement in Indonesia is still weak } \\
\text { although there are various kinds of NGO } \\
\text { which watch it. }\end{array}$ & $\begin{array}{l}\text { 3b. Indonesia law enforcement is still weak } \\
\text { despite being watched by various kinds of } \\
\text { NGO. }\end{array}$ \\
\hline 4a. He is lonely because he has no friend. & 4b. His loneliness is due to his being friendless \\
\hline $\begin{array}{l}\text { 5a. The old woman felt peaceful after she } \\
\text { lived in a quiet place. }\end{array}$ & $\begin{array}{l}\text { 5b. The old woman's peace accompanied her } \\
\text { life in a quiet place. }\end{array}$ \\
\hline
\end{tabular}

Note that grammatical metaphor in terms of experiential metaphor is naturally used in the written language in the description of science and technology, which is associated to: objectivity, impersonality, technicality, and practicality. Thus, the lexicogrammatical realizations of experiential metaphor are characterized by such features as (a) dominant use of relational process, (b) in the passive voice, and (c) with low degree of grammatical intricacy and high degree of lexical density. Grammatical intricacy is associated with the number of clauses in a clause complex and lexical density is based on the less number of lexical categories in the clause.

Interpersonal metaphor on the other hand, is incongruent coding involving types of clause involving mood and modality. Normally, the congruent coding of a statement is realized with a declarative, a question with an interrogative, and a command with an imperative. Note that an offer does not have an unmarked congruent realization in mood. Here are some examples of transference of mood from congruent coding into incongruent coding in terms of interpersonal metaphor of mood.

A statement expressed in the interrogative mood.

a. That is not the character of a university student. $\rightarrow$

Is that the character of a university student?

b. You cannot repay your parents' merit. $\rightarrow$

Can you repay your parents' merit?

A statement expressed in the imperative mood.

a. Ali : Where is my new bag, Mom?

Mom : I put somewhere in the cupboard. $\rightarrow$

Look for it in the cupboard! 
b. Student : What is the meaning of this word, Sir?

Teacher : You can find it yourself in the dictionary. $\rightarrow$

Find it yourself in the dictionary!

A command expressed in the interrogative mood.

a. Switch on the air-conditioner! $\rightarrow$

Could you switch on the air-conditioner?

b. Don't make noise in the hospital! $\rightarrow$

Will you not make noise in the hospital, please?

A command expressed in the declarative mood.

a. Accompany me to go to market! $\rightarrow$

You must accompany me to go to market.

b. Don't challenge your father! $\rightarrow$

You should not challenge your father.

A question expressed in the declarative mood.

a. Do you know her name? $\rightarrow$

I ask you whether you know her name.

b. Has he read the novel? $\rightarrow$

I'd like to know if he has read the novel.

A question expressed in the imperative mood.

a. Who hasn't got the hand-out? $\rightarrow$

Raise your hand if you haven't got the hand-out.

b. Can you teach without a notebook this time?

Tell us ifyou can teach without a notebook this time.

In many instances a question may be answered in three different moods: declarative, imperative or interrogative.

A: Where is my notebook?

B: It is in the cupboard. (Declarative)

Find it in the cupboard. (Imperative)

Have you looked for it in the cupboard? (Interrogative).$^{5}$

\section{Earlier Studies}

Based on the exploration so far made through journals and articles in various websites, there is no works conducted earlier which are concerned with the application of the theory of interpersonal metaphor of mood to the verses of the HQ. Thus, this can be claimed to be the first work to apply the theory to the verses of the HQ. Some authors did apply the theory to some discourses but not the HQ.

${ }^{5}$ Suhadi, Course in English, p. 210-214. 
Taverniers (2004) from Ghent University, Belgium wrote an article entitled Interpersonal Grammatical Metaphor as Double Scoping and Double Grounding. This article focuses on the notion of interpersonal grammatical metaphor as understood in Halliday's model of Systemic Functional Linguistics (SFL). First, the concept of grammatical metaphor as developed in SFL is reviewed and its relation to comparable concepts developed in other linguistic schools is specified. On the basis of a general semiotic-functional characterization of the interpersonal sign in terms ofscoping and grounding, she defines interpersonal grammatical metaphor as involving a doubling of semiosis, viz. a doubling of scoping in its structural-realizational dimension, and a doubling of grounding in its semantic-functional dimension. Thus, this study focuses on the writer's perception of the theory of interpersonal grammatical metaphor but it does not at all touch the application of the theory. ${ }^{6}$

Yanning (2013) wrote an article entitled A Corpus-based Study of Interpersonal Grammatical Metaphor in Spoken Chinese. He claimed that it was the first attempt to explore the use of interpersonal grammatical metaphor in spoken Chinese. The study developed a framework for the identification and categorization of interpersonal grammatical metaphor in the language. On the basis of the framework, a large corpus of spontaneous conversation was analyzed to reveal how different types of interpersonal grammatical metaphor were distributed. The analysis showed that spoken Chinese had a preference for certain types of metaphorical expression. The study also investigated the relationship between interpersonal grammatical metaphor in spoken Chinese and its immediate context of situation, demonstrating how the deployment of interpersonal grammatical metaphor was affected by the topic of conversation and the social status between speaker and hearer. This work has nothing to do with the topic under study as it was an attempt to explore the use of interpersonal grammatical metaphor in spoken Chinese. ${ }^{7}$

Perdana and Saragih (2013) from State University of Medan applied Halliday's theory of interpersonal metaphor to investigate a spoken discourse in Bahasa Indonesia from a TV program called Mata Najwa's Talk Show as the corpus. The analysis was based on the theory of interpersonal metaphor of both mood and modality. The result showed that metaphor of mood was more dominantly used reaching $94.85 \%$ and metaphor of modality was only 5.14\%. Metaphor of mood was more dominant because the message was concerned about political interaction which used the patterns of mood in carrying the burden for making different interpretation in the contextual occurrences. But, again it did not talk about the application of the theory to analyze verses of the HQ as the present study does. ${ }^{8}$

${ }^{6}$ Miriam Taverniers, Interpersonal Grammatical Metaphor as Double Scoping and Double Grounding: In Current Issues in Linguistic Theory 236 (Amsterdam: Benjamins, 2004), p. 5-33.

${ }^{7}$ Yang Yanning, "A Corpus-based Study of Interpersonal Grammatical Metaphor in Spoken Chinese," in Language Sciences, Vol. 38, p. 1-21.

${ }^{8}$ Elisa Perdana and Amrin Saragih, "Interpersonal Metaphor in Mata Najwa's Talk Show," in Linguistic, Vol. 2, No 1. 


\section{Data Analysis}

The data adopted from the verses of the Holy al-Quran are classified according to the classification of interpersonal metaphor of mood proposed by Halliday (1994: 363).

\section{Statement Conveyed in the Indicative Mood}

It is unmarked when a statement is expressed in the form of an indicative mood. Many verses of the HQ indicate this congruent coding as quoted below. (a) Q.S. al-Baqarah/2: 29,

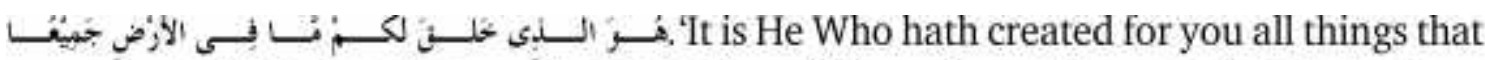
are on earth. ${ }^{9}$ (b) Q.S. al-Baqarah/2: 255, Allah. There

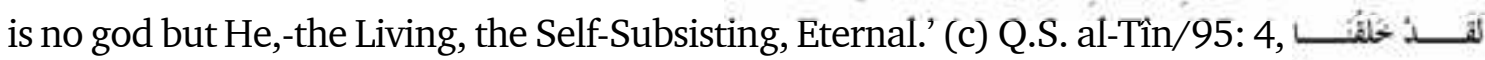

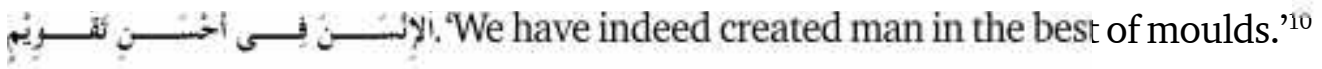

The three verses of the HQ quoted above are in the indicative mood. In (a) Huwa

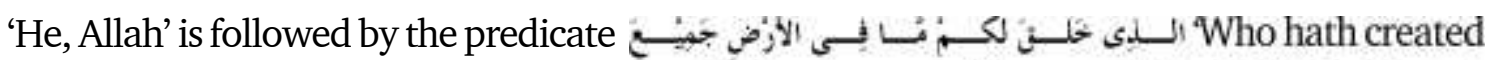
for you all things that are on earth.' In (b) the first participant Allâhu 'Allah' with /u/ endingindicating a nominative case is followed by the complement lâilâha 'no god'and

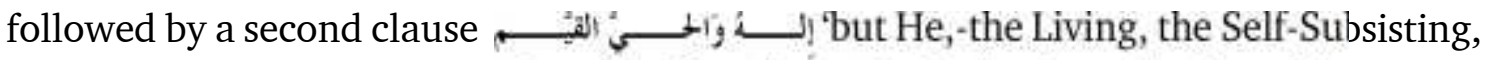
Eternal', to elaborate the meaning of the first clause. In (c) the clause begins with a harf altaukîd' intensifier' laqad'indeed' and the first participant is $\mathrm{Na}$ 'We, Allah" criticized to the past tense verb khalaq 'created' and then followed by the goal insâna 'men' and an adjunct

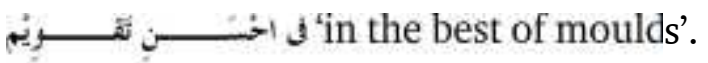

\section{Statement Conveyed in the Imperative Mood}

In many instances the mood of an expression switches from a congruent coding into an incongruent one. The following data show that in some verses of the HQ statements

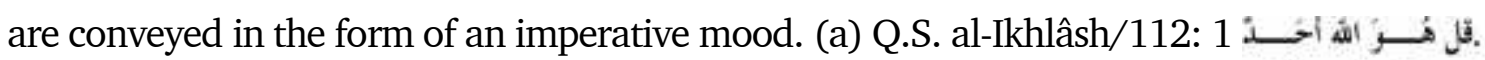

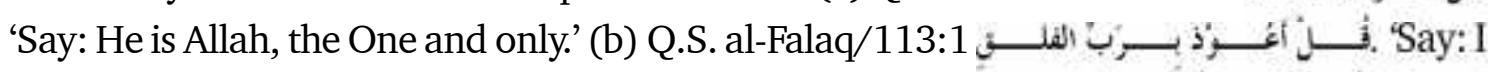

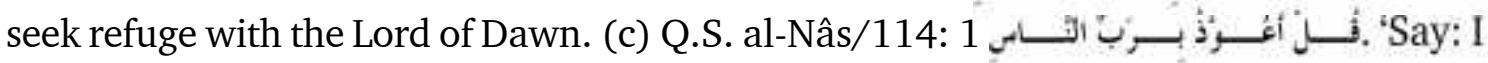
seek refuge with the Lord and Cherisher of Mankind.'

Observe that in (a) the main clause is in the imperative mood Qul 'Say' but the important message is given in the projected clause, which is in the indicative mood or statement i 'He is Allah, the One and Only'. In (b) the main clause is also expressed in the form of an imperative mood Qul 'Say' and the important message is given in the indicative

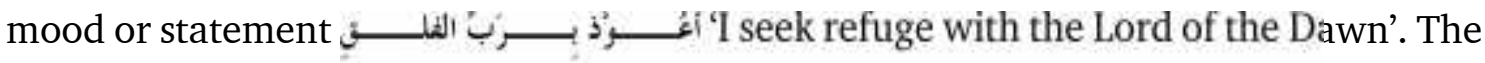

\footnotetext{
${ }^{9}$ Nazri Adlani, et al., al-Qur'an: Terjemah Indonesia (Jakarta: Sari Agung, 2008).

${ }^{10}$ Abdullah Yusuf Ali, the Holy Qur'an: Text, Translation and Commentary (Maryland: Amana Corp., 1983).
} 
same happens in (c) in which the main clause is also expressed in the form of an imperative mood Qul 'Say' and the important message is given in the indicative mood or statement

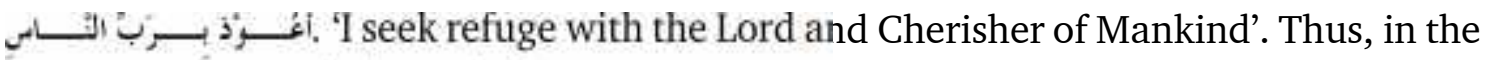
three verses quoted above the important messages which are generally conveyed in the indicative mood are expressed in the imperative mood.

\section{Statement Conveyed in the Interrogative Mood}

In some verses ideas which are commonly expressed in the statement are expressed in the form of a question or interrogative mood as in the following. (a) Q.S. al-Zumar/

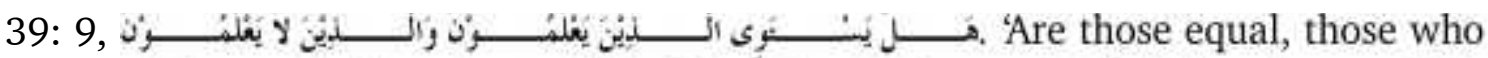

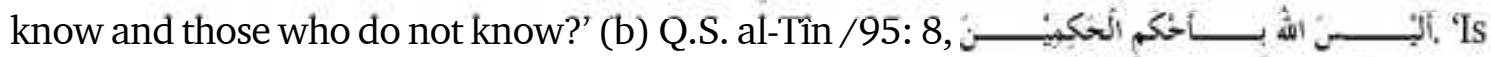

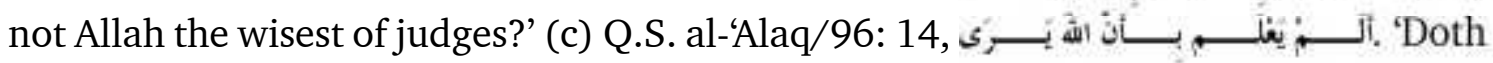
he not know that Allah doth see (what he has done)?'

In (a) the clause is indeed conveyed in the form of a question as identified from the first word which makes use of the question word Hal 'Are those ...?' and it is followed by

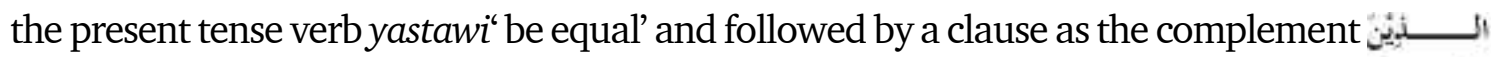

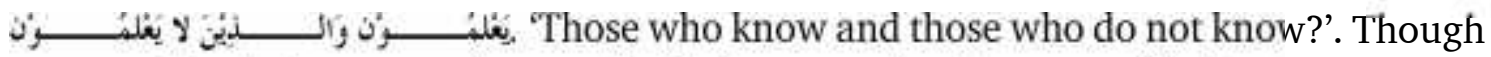
expressed in the interrogative mood, this clause carries the sense of indicative meaning "Those who know are not equal to those who do not know." In (b) the clause begins with a modal adjunct of polarity carrying negative meaning A-laisa'Is not ..,' and it is followed by the first participant as the token Allâhu 'Allah' and followed by the second participant as the value بـ the wisest of judges?'. As also happens in (a), in (b) the interrogative clause also carries an indicative mood, meaning Allah is the wisest of judges. In (c) the clause is also in the interrogative beginning with A-lam 'Don't ...' and it is followed by a present

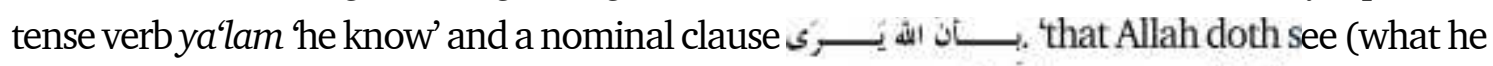
has done)?', as the complement of the verb. This verse carries the sense of indicative mood meaning He should know that Allah does see (what he has done).

\section{Command Conveyed in the Imperative Mood}

The following quoted verses of the HQ carry no grammatical metaphor as the meanings are congruently expressed. The verses carry the meanings of command which are conveyed

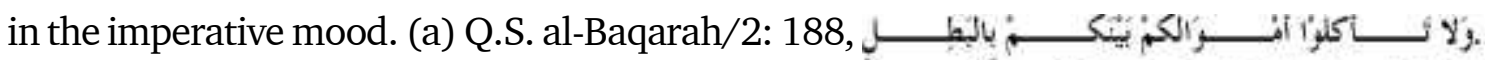
'And do not eat up your property among yourselves for vanities,' (b) Q.S. al-Tahrîm/66: 6,

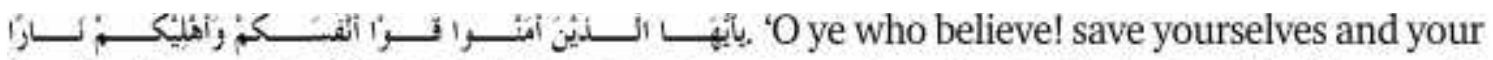

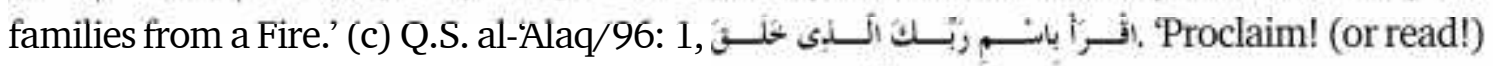
in the name of thy Lord and Cherisher, Who created.'

In (a) the clause is in the form of a negative imperative (fil nahi)with wa-lâta'kulu 'and don't (you) eat'. In (b) the imperative is identified from the imperative verb (fil amr) 
$q \hat{u}$ 'save', in (c) from the imperative verb (fi'l al-amr) Iqra' 'read', Thus, the three verses indicate that some verses in the HQ are also expressed congruently; commands are expressed in the imperative mood.

\section{Command Conveyed in the Indicative Mood}

Unlike the verses adoptedabove, the verses of the HQ quoted below convey interpersonal metaphor of mood in which commands are conveyed in the indicative mood. (a) Q.S. al-

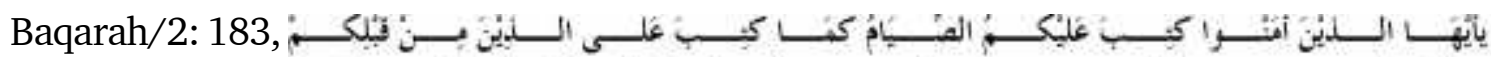

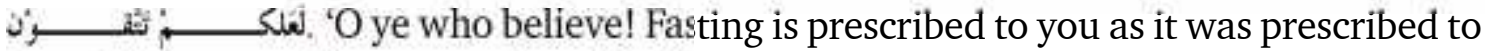

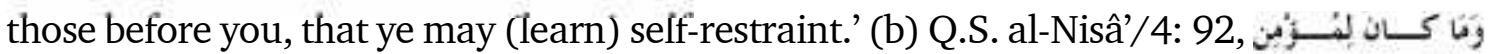

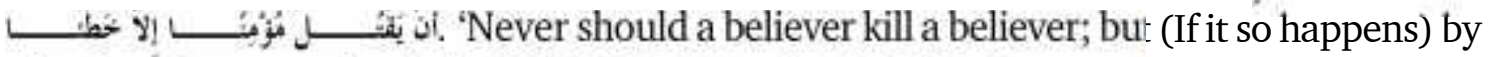

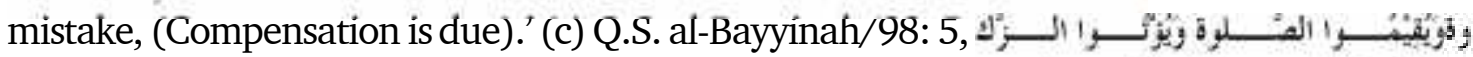

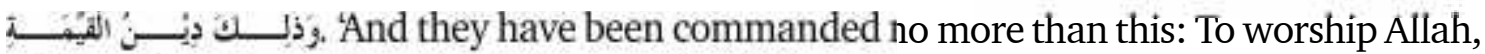
offering Him sincere devotion, being true (in faith); to establish regular prayer; and to practice regular charity; and that is the Religion Right and Straight.'

In (a) the interpersonal metaphor is found in the form of an indicative mood with the verb kutiba 'prescribed'; but actually, this verse is a command to the believers to fast in the month of Ramadhan as also prescribed to people before Muhammad, which is commonly expressed in the imperative mood. In (b) this verse is also in the indicative mood but it carries the meaning of negative imperative. It is identified from the form of the verb in the present tense ay-yaqtula 'kill',not in the imperative form. The paraphrase of this verse is a believer should never kill another believer except by mistake, or interpreted into never kill a believer except by mistake. In (c) the verse is also in the indicative mood identified from the passive verb umiru 'they are commanded'. The message commanded is to worship Allah, offering Him sincere devotion, being true (in faith); to establish regular prayer; and to practice regular charity; and that is the Religion Right and Straight.' Thus, in the three verses quoted above, the commands are conveyed in the indicative mood.

\section{Command Conveyed in the Interrogative Mood}

It is also common when people express a command in the interrogative mood. Surprisingly, some verses of the HQ also apply this linguistic property as in the verses quoted below. (a)

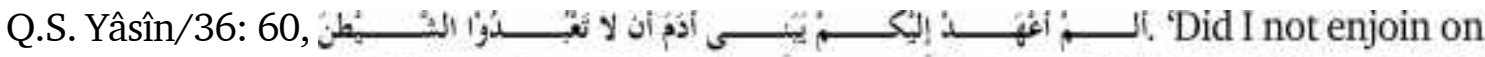
you, O ye Children of Adam, that ye should never worship Satan?' (b) Q.S. Yâsîn/36: 73,

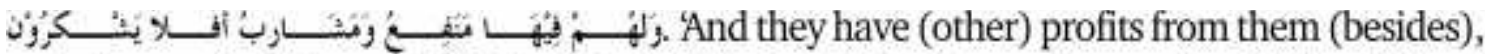

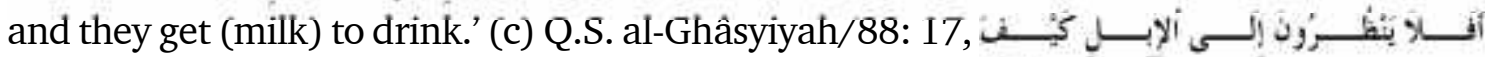

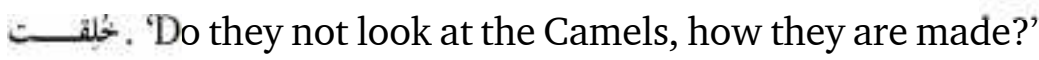

Note that in (a) this verse is in the interrogative mood beginning with the phrase $A$ -

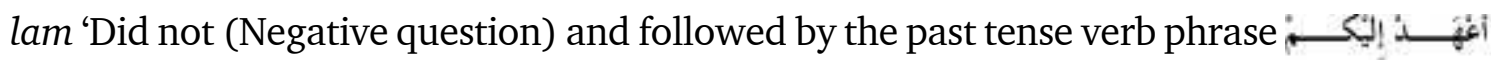




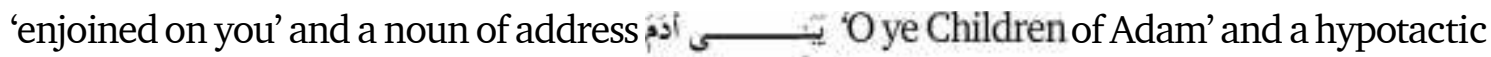

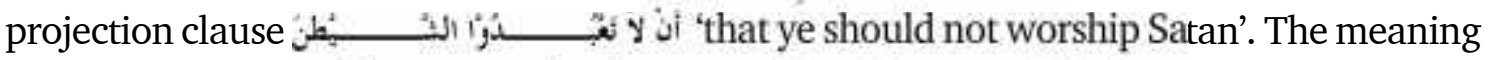
of this verse is not asking a question but a warning: Never worship Satan, O ye Children of Adam.' In (b) the interrogative clause is found at the end of the verse with the question word أفـــ 'Will they not then be grateful?'. This clause carries the meaning of imperative to the third person plural they (Non-believers) to mean Be grateful, $O$ the nonbelievers, as they have enjoyed benefits from animals and get milk from them. In (c) the verse begins with

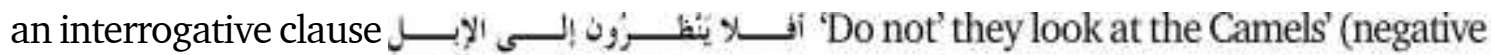
question) and it is followed by a hypotactic enhancement clause made'.This verse can be interpreted as carrying the sense of a command Look at the camels how they are made; but, it is conveyed in the interrogative mood.Thus, the three verses quoted above represent evidence that the HQ also applies interpersonal metaphor of mood with the transference from imperative into interrogative mood.

\section{Question Conveyed in the Interrogative Mood}

When a question is conveyed in the interrogative mood, it is said to be congruent coding. No grammatical metaphor is found in such coding. In the HQ many verses are of

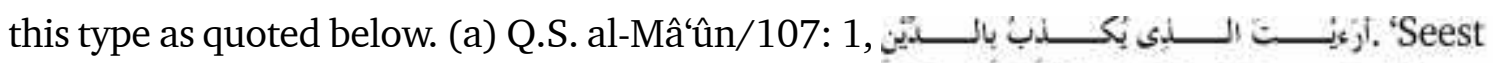

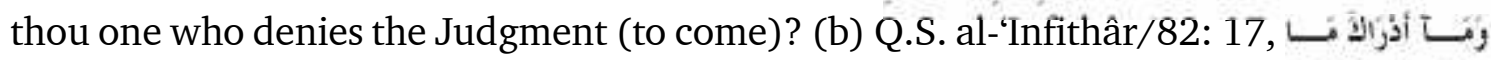

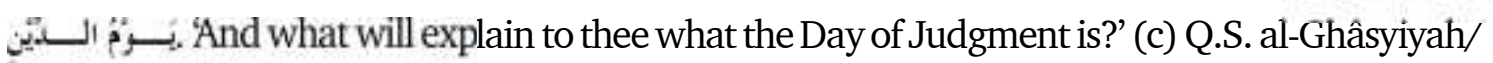

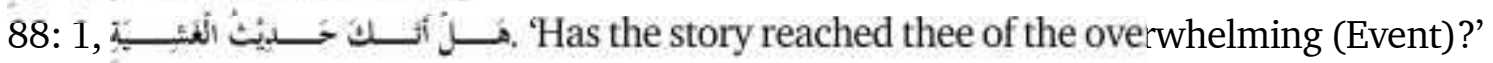

Observe that all the three verses quoted above begin with an interrogative word. In (a) it begins with a question word $A$ 'Did', in (b) it begins with a question word Wa-mâ 'and what', and in (d) it begins with a question word Hal 'Has'.

\section{Question Conveyed in the Indicative Mood}

Many instances of questions which are normally expressed in the interrogative mood are sometimes expressed in the indicative mood. Such transference is found in some

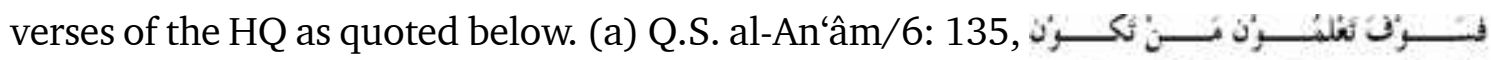

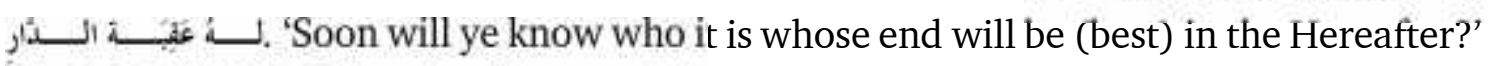

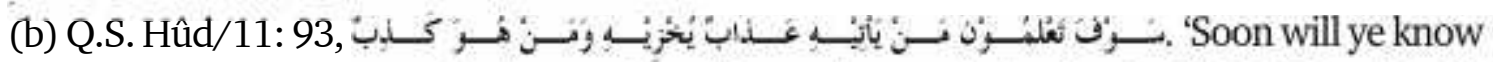
who it is on whom descends the penalty of ignominy; and who is a liar?' (c) Q.S. al-Isrâ'/ 17: 84, But your Lord knows best who it is that is best guided on the Way."'

In (a) the verse is in the indicative mood of hypotactic projection 'Soon will ye know', but the main idea is found in the projected clause الــدار 'Who it is whose end will be (best) in the Hereafter', which is in the question form. The same happens in (b) in which the verse is also in the indicative mood of hypotactic 
projection soon will ye know' and the main idea is on the projected clause

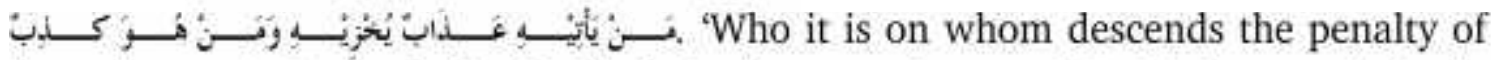
ignominy; and who is a liar', which is in the interrogative mood. In (c) the verse is also in the indicative mood of hypotactic projection 'but your Lord knows best'

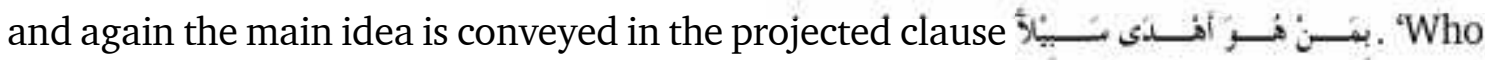
it is that is best guided on the way' which is in the question. Thus, the three verses quoted above convey meanings of interrogative mood which are expressed in the indicative mood. Thus, the three verses give evidence that the HQ applies transference of mood.

\section{Question Conveyed in the Imperative Mood}

Though not quite common, a question can sometimes be conveyed in the imperative mood; even, some verses of the HQ apply this linguistic fact as adopted below. (a) Q.S. al-

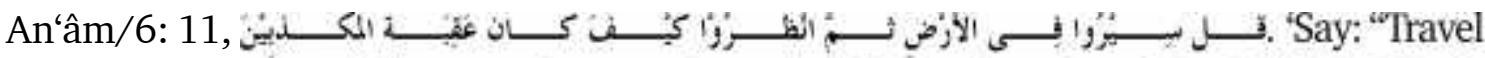
through the earth and then see what was the end of those who rejected Truth." (b) Q.S. al-

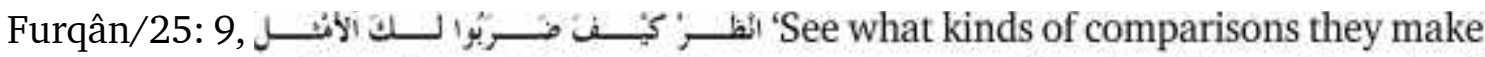

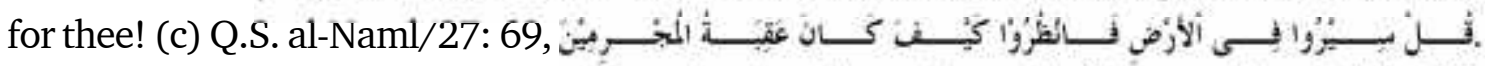
'Say: "Go ye through the earth and see what has been the end of those guilty (of sin)."'

Observe that in (a) the verse begins with an imperative verb Qul 'Say' and followed

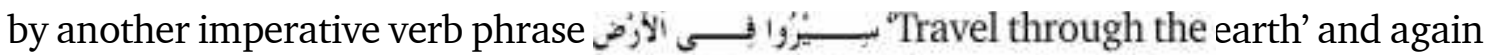

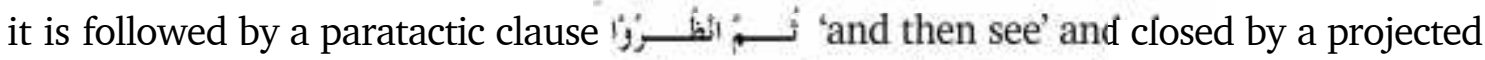

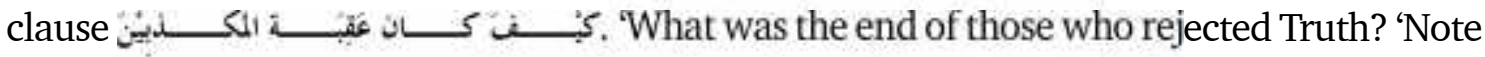
that the important message is found in this projected clause (question) which is conveyed in the imperative mood (the main clause). In (b) the main clause is in the form of an ك' 'الأثــــ ' what kinds of comparisons they make for thee', which is a question and constitutes the main idea of this verse; but, the main clause is in the imperative mood. In (c) the verse is almost similar to (a). It also begins with the imperative verb Qul 'say' and it is followed by another verb phrase 'go ye through the earth' which is also in the

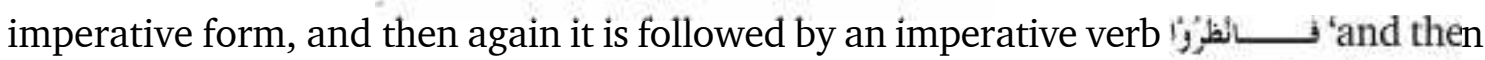

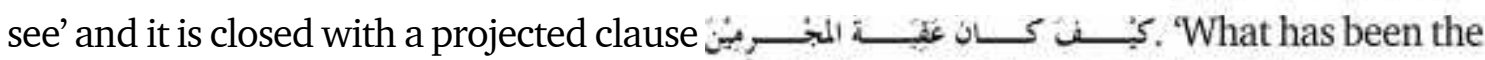
end of those guilty (of sin)' as the complement of the last verb ' ' message lies on the last clause which is in the interrogative mood but the main clause is in the imperative mood. Thus, the three verses quoted above consist of questions which are conveyed in the imperative mood.

\section{Findings}

The goal of this work suggests that this is to confirm whether the theory of Grammatical Metaphor in terms of Interpersonal Metaphor of mood postulated by Halliday (1994) is 
relevant to be applied to Godly verses of the Holy al-Qur'an. Three verses were adopted as samples for each type of mood. The result shows that all types of mood transference are found in verses from various Surah 'chapters' in the HQ. Some verses use congruent coding in conveying messages. A statement is conveyed in the indicative mood as in the Q.S. al-Baqarah/2: 29, Q.S. al-Baqarah/2: 255, and Q.S. al-Tîn/95: 4; a command is conveyed in the imperative mood as in Q.S. al-Baqarah/2: 188, Q.S. al-Tahrîm/66: 6, and Q.S. al'Alaq/96: 1; and a question is conveyed in the interrogative mood as in Q.S. al-Mâ‘ûn/107: 1, Q.S. al-Infithâr/82: 17, and Q.S. al-Ghâsyiyah/88: 1.

The interpersonal metaphoric coding is found in some verses from various other Surah 'chapters'. A statement conveyed in the imperative mood is found in Q.S. al-Ikhlâsh/ 112: 1, Q.S. al-Falaq/113: 1, and Q.S. al-Nâs/114: 1; and a statement conveyed in the interrogative mood is found in Q.S. al-Zumar/39:9, Q.S. al-Tîn/95: 8, and Q.S. al-Alaq/ 96: 14. A command conveyed in the indicative mood is found in Q.S. al-Baqarah/2: 183, Q.S. al-Nisâ'/4: 92, and Q.S. al-Bayyinah/98: 5; whereas a command conveyed in the interrogative mood is found in Q.S. Yâsîn/36: 60, Q.S. Yâsîn/36: 73, and Q.S. al-Ghâsyiyah/88: 17. Further, a question which is conveyed in the indicative mood is found in Q.S. al-An'âm/6: 135, Q.S. Hûd/11: 93, and Q.S. al-Isrâ'/17: 84, whereas a question which is conveyed in the imperative mood is found in Q.S. al-An'âm/6: 11, Q.S. al-Furqân/25: 9, and Q.S. al-Naml/ 27: 69. Thus, Halliday's postulation on the theory of interpersonal metaphor of mood does apply to the data and the result constitutes convincing evidence that all types of transference of mood are found in the Godly verses of the Holy al-Quran.

\section{Conclusion}

Exploration throughout the content of the Holy al-Quran which consists of 114 Surah 'chapters' and 6632 ayah 'verses' and selection of verses which are relevant to each type of mood have led to a deduction that all types of interpersonal metaphor of mood are found in the Holy book. The transference covers all the three types of mood. Some indicative moods are expressed in the interrogative and imperative, some imperative moods in the indicative and interrogative, and some interrogative moods in the indicative and imperative. It means that Halliday's theory of Interpersonal Metaphor of mood can be justified as an adequate linguistic theory. However, the congruent coding does undeniably exist; that is, a statement conveyed in the indicative mood, a command in the imperative mood and a question in the interrogative mood.

\section{References}

Adlani, Nazri et. al. Al-Qur'an Terjemah Indonesia. Jakarta: Sari Agung, 2008.

Ali, Abdullah Yusuf. The Holy Qur'an: Text, Translation and Commentary. St Brentwood Maryland: Amana Corp, 1983. 
Halliday, M.A.K. An Introduction to Functional Grammar. London: Edward Arnold, 1994.

Mahsun. Metode Penelitian Bahasa: Tahapan Strategi, Metode dan Tekniknya. Jakarta: RajaGrafindo Persada, 2007.

Suhadi, Jumino. Course in English Functional Grammar. Medan: LPPM UISU Press, 2015.

Perdana, Elisa, and Saragih, Amrin. "Interpersonal Metaphor in Mata Najwa's Talk Show," in Linguistica, Volume 2, No 1. Medan: Universitas Negeri Medan, 2013.

Taverniers, Miriam. Interpersonal Grammatical Metaphor as Double Scoping and Double Grounding. Belgium: Ghent University Press, 2004.

Yanning, Yang. "A Corpus-based Study of Interpersonal Grammatical Metaphor in Spoken Chinese," in Language Sciences Volume 38, 2013. 